Forthcoming in Colin Marshall (ed.), Comparative Metaethics: Neglected Perspectives on the

Foundations of Morality, Routledge. Please cite final published version.

\title{
Species and the Good in Anne Conway's Metaethics
}

\author{
John Grey \\ Michigan State University
}

\section{Introduction}

Many Neoplatonist thinkers hold that moral facts are, in the first instance, evaluative facts about states of being rather than deontic facts about actions. At least for a human, being wise is good; being "thoroughly mixed with the body" is bad (Enneads I.2, 135); being rational is better than being irrational; and so on. As these examples indicate, such evaluations are most easily construed in relation to a particular kind or species. What is a defect in a human may not be a defect in another sort of being. As Plotinus observes,

"living" means different things in different contexts; it is used in one way of plants, in another of irrational animals, in various ways by things distinguished from each other by the clarity or dimness of their life; so obviously the same applies to "living well."

(Plotinus, Enneads I.4, 181)

This suggests an account of an important set of evaluative facts, namely those regarding what states are good or bad (or better or worse) relative to a given species. It is worse for a human to be blind than to be sighted, but the same does not hold for a deep-sea lobster. Why? Being sighted is in the nature of human life and not in the nature of deep-sea lobster life. Moreover, an account along these lines has the advantage of being connected to ordinary experience. We derive our knowledge of the nature of a species or kind by observing lots of individual members of that species or kind. Insofar as the facts about what states are good or bad for an individual follow from what kind of thing it is, our knowledge of these evaluative facts does not require any special form of perception or intuition. ${ }^{1}$

It is not all smooth sailing. Neoplatonist authors typically endorse some version of the "great chain of being," and on such a picture at least some evaluative facts about states of being are not merely relative to the kind or species of thing that has that state. ${ }^{2}$ Being

\footnotetext{
${ }^{1}$ Over and above the basic questions about what these evaluative facts are and how we learn of them, a contemporary metaethicist might also ask what reason there is to think that such evaluative facts are prior to other sorts of moral facts, such as facts about how we ought to act. Authors such as Conway do not directly address this question, as far as I can see, so I pass over it. For an overview of the metaethical issues involved in the relationship between the evaluative and the deontic, see Michael Smith 2005, 10-21.

${ }^{2}$ A clear example of this sort of picture can be found in, e.g., Book III of Marsilio Ficino's Platonic Theology; see Ficino 2001.
} 
human is better than being a deep-sea lobster-full stop. Two metaethical difficulties are posed by such absolute evaluative facts about states of being. Prima facie, such facts cannot be grounded in the natures of the individuals possessing or lacking those states, since the individuals could hardly have had a different (better!) nature. Nor can we learn about such things by observing what is normal or natural for the individual or for its species. On the face of it, it is entirely normal and natural for a lobster not to be a human. Why then is this state worse for it than being human would be? What sense can be made of such a claim, and by what mode of inquiry could we come to learn whether it is true or false?

Here I examine the way that these questions arise for Anne Conway, an early modern philosopher heavily influenced by Neoplatonism. Her strategy for addressing these issues is noteworthy because it is derived from a sophisticated theory of essence. ${ }^{3}$ Conway recognizes that in order to make sense of species-independent facts about which states of being are better or worse than others, she must deal with the modal issues that are involved in making sense of statements such as, "It would be better for this deep-sea lobster to be a human." I will argue that Conway rejects essentialism about species membership primarily because it would entail that "no creature could attain further perfection and greater participation in the divine goodness" (CC 32) than the limits of their species permitted. ${ }^{4}$ As a consequence, the essence of a particular human being does not include her humanity. And once essentialism about species membership is off the table, there is no problem with taking species-independent facts about an individual's good to be grounded in that individual's nature after all.

Concerns such as these may seem quite distant from current metaethical interests, and in many ways they are. Nevertheless, I will conclude by arguing that Conway's work bears on a prominent family of contemporary views about an individual's good that draw on the notion of an ideally rational, ideally informed version of that individual. As I shall argue, the construction of such an ideal counterpart typically involves essentialist presuppositions similar to those that Conway identifies and rejects in her investigations into species and the good.

\section{Background: Conway's Metaphysics}

Since Anne Conway has not (yet) been widely included as part of the canon of early modern European philosophers, a brief overview of her biography and philosophical system will be helpful. ${ }^{5}$

Conway, née Anne Finch, was born in 1631 to Sir Heneage Finch and Elizabeth Cradock. Heneage Finch was the Recorder of the City of London-a senior judge and highlevel government functionary_as well as Speaker of the House of Commons. We know

\footnotetext{
${ }^{3}$ See Peter Loptson 1982 for extensive discussion of Conway's peculiar form of essentialism; I focus in what follows only on those aspects of Conway's view that pertain to the metaethical issues raised above.

${ }^{4}$ Citations of Allison P. Coudert and Taylor Course's translation of Conway's Principles are to Conway 1996, hereafter 'CC'. Where the Latin translation of the lost original manuscript is consulted, citations are also provided to Peter Loptson's edition, Conway 1982, hereafter 'L'. ${ }^{5}$ For more detailed discussion of Conway's life and her interactions with other philosophers and figures of interest, see Loptson 1982 and Sarah Hutton 2004. Useful discussions of Conway's shifting intellectual relationship with More over the years may be found in Allison Coudert 1975 and Jasper Reid 2012, 255-278.
} 
little of Conway's education, but based on the testimony of those familiar with her, she was fluent in Latin and had at least some knowledge of Greek. Her education took a distinctively philosophical turn in 1650, when — at the age of nineteen — she began a correspondence with Henry More. Although Henry More is little studied today, he was the most prolific of the Cambridge Platonists; indeed, some scholars have made the case that More was the most influential living philosopher in the latter half of the seventeenth century (read: after Descartes's death). ${ }^{6}$ Under More's tutelage, Conway studied the works of Plato and Plotinus, and is thanked in More's own works as having provided constructive but penetrating criticism of his arguments. She also learned the intricacies of Cartesian philosophy, though she did not herself become a Cartesian. Her correspondence with More indicates that she frequently raised objections to both Morean and Cartesian philosophy. In the earliest biography of Henry More, the author recalls More describing Conway as "one, that would not give up her Judgement entirely unto any" (cited in the appendix to L 237). In spite of the fact that she was often critical of More's views, the two remained close friends for almost Conway's entire life. After her death in 1679, More and another of Conway's close friends, Francis Mercury van Helmont, worked to have her philosophical notebook translated into Latin and published. This was finally accomplished in 1690, when the translated contents of the notebook were published as the Principles of Most Ancient and Modern Philosophy.

The work is short — the Latin text runs 82 pages with modern typesetting-but extremely dense. Here I will not canvass the whole of her Principles, though I might note by way of advertisement that, among other points of interest, she provides a number of striking objections to both substance dualism and property dualism, and anticipates a version of Leibniz's argument against absolute space and time. My focus here will be on the root structure that feeds into Conway's metaethics.

Conway's system presupposes a form of Christian Theism, although her Christianity is an unorthodox fusion of Platonism, Kabbalism, and early Quakerism. ${ }^{7}$ Much of her metaphysics aims at drawing out the consequences of her conception of God and God's relationship to creation. On the view she develops, God is a unique, purely spiritual substance with a number of fairly traditional divine attributes: "God is spirit, light, and life, infinitely wise, good, just, strong, all-knowing, all-present, all-powerful, the creator and maker of all things" (CC 9). No attempt is made in the Principles to justify or argue for the claim that God exists; no attempt is made to show that God is unique; and no attempt is made to show that God has this particular list of attributes. This conception of God is a foundational element of Conway's system. It is important for us because, as the list of God's attributes reveals, God has a number of paradigmatically moral properties.

Conway also holds that God is really distinct from, but intimately connected to, creation:

[God] is also in a true and real sense an essence or substance distinct from his creatures, although not divided or separate from them but present in everything most intimately in the highest degree. (CC 9)

\footnotetext{
${ }^{6}$ Reid 2012, 1.

${ }^{7}$ On Conway's Platonism, see Hutton 2018, 242-246; on her kabbalism, see Coudert 1975; on her Quakerism, see Hutton 2004, ch. 9.
} 
Both the real distinction of God from creation and God's intimate presence in creation are important foundational elements of her system. The fact that God is really distinct from any created substance serves to distance Conway from substance monists such as Spinoza, who "confuse God with his creatures" (CC 31). Yet the intimate presence of the divine in all creatures is also crucial for Conway's picture. It leads her to the view that all things must inherit certain of God's attributes, at least in some degree.

This point is of particular importance for Conway's metaethics. She holds that in any act of creation, there are certain attributes that the created thing can inherit from the creator (or "communicable" attributes), and others that cannot be so inherited (or "incommunicable" attributes). Her examples of incommunicable attributes include the attribute of being a self-subsisting entity or "ens per se subsistens," being immutable, and being most perfect (CC 45; L 108). By contrast, "The communicable attributes are that God is spirit, light, life, that he is good, holy, just, wise" (CC 45), and so on. Notably, although God has numerous attributes that creatures do not — and cannot-inherit, these are in the first instance purely metaphysical features of God. The attributes that creatures can and at least to some degree do inherit from God include his moral properties: being good and being just. Thus, as Sarah Hutton (2018) has recently argued, there is a sense in which Conway construes properties such as goodness and justice as specific forms of Godlikeness. ${ }^{8}$

Perhaps the most distinctive element of Conway's system, however, is her monistic view of the created world. She reasons on the basis of the fact that God's immutability is not communicable to creatures that there can be at most "three kinds of being [Triplex...Entium classis]" (CC 24, L 82):

The first is altogether immutable. The second can only change toward the good, so that which is good by its very nature can become better. The third kind is that which, although it was good by its very nature, is nevertheless able to change from good to good as well as from good to evil. (CC 24)

Conway's inference to this tripartite ontology presupposes, first, that although God has many attributes, immutability with respect to the good is the attribute that defines the kind of being he is. She also presupposes that there are only two ways for a being to be changeable or mutable with respect to the good. Either (i) it has the potential to change only for the better, or (ii) it has the potential to change both for better and for worse. (The possibility of a being that can change only for the worse, only becoming less perfect ad infinitum, she rules out as

\footnotetext{
${ }^{8}$ Notably, Hutton holds that, "Conway's conception of goodness is primarily metaphysical rather than moral" (230). Her main argument for this claim is that Conway's account of the good focuses so much on its ontological or metaphysical side that it is not usefully actionguiding; it "brings us no nearer to knowing what kind of conduct incurs punishment" (241). This highlights a genuine difficulty in understanding Conway's treatment of the good and somewhat undermines my proposal to examine her as a metaethical thinker. However, I suspect that this also overstates the problem a bit; given Conway's lengthy list of God's attributes, it seems possible to make reasonable inferences about how an individual ought to strive to emulate the divine in at least some cases. For example, in virtue of the fact that God is life, we might expect Conway to see the promotion of life, whether one's own or another's, as good. Acts of violence and self-harm, on such a view, would qualify as sinful and worthy of punishment.
} 
incompatible with the premise that all creatures inherit some degree of God's goodness.) Given these presuppositions, however, we arrive at Conway's tripartite ontology.

She interprets this ontology as describing the following situation. There is a divine substance, God, which produces "by generation or emanation [generatio vel emanatio]" (CC 25, L 84) a mediating substance, a being mutable in the sense that it can always become better or more godlike. ' The divine substance then works through the mediating substance to produce created substances - including ourselves and other finite individuals - which are mutable in the sense that they can always become better or worse, more or less godlike.

The most significant consequence of this ontology is that all created individuals are of the same kind. As many scholars have observed, this is the central part of Conway's case against the various forms of mind-body dualism that she considers and rejects in the course of her Principles. ${ }^{10}$ The dualism of Descartes fails, for example, because the distinction between thought and extension does not mark an ontological difference; both spirits and bodies are created substances, and any further differences among them are mere a matter of modes or properties, rather than of substance. ${ }^{11}$ And the fact that a substance bears some extended modes does not entail that it bears no modes of thought. Thus:

$[\mathrm{C}]$ reation is one entity or substance in respect to its nature or essence, as demonstrated above, so that it only varies according to its modes of existence, one of which is corporeality. There are many degrees of this so that any thing can approach or recede more or less from the condition of a body or spirit. Moreover, because spirit is the more excellent of the two in the true and natural order of things, the more spiritual a certain body becomes...the closer it comes to God... (CC 42)

Conway is thus an essence monist. she holds that all created individuals have the same nature or essence. ${ }^{12}$ She relies upon this point throughout the remainder of the Principles to undermine

\footnotetext{
${ }^{9}$ The mediating substance she usually calls "Christ," and not merely as a metaphor. She takes the mediating substance to be the historical Jesus; see CC Chapter 5. However, this fact does not seem to play much role in the development of her system, which relies more on a priori argument than appeal to biblical authority.

${ }^{10}$ Some valuable discussions of the connection between Conway's ontology and her philosophy of mind appear in Jane Duran 1996, Jennifer McRobert 2000, and Julia Borcherding forthcoming.

${ }^{11}$ I develop one of Conway's versions of this argument at length in John Grey 2017.

${ }^{12}$ There are stronger and weaker readings of Conway's claim that creatures do not differ in their "substance or essence." On one reading_-endorsed primarily by Hutton 2004 and Christia Mercer 2012 and 2015-Conway is committing herself to a form of existence monism about created substance. On another reading, endorsed by Loptson 1982, Duran 1989, Jacqueline Broad 2002, Marcy Lascano 2013, and Grey 2017, Conway merely intends to claim that creatures are not individuated from one another by their essential features (since their essence is to be created individual), leaving open the possibility that individual creatures are individual substances. For an alternative to these two readings, see Jessica Gordon-Roth 2018. This disagreement may be relevant insofar as Conway's metaethics is founded upon her metaphysics of essence; however, I aim to sidestep this issue as much as possible.
} 
a variety of different forms of dualism or materialism. ${ }^{13}$ Conway wields this monistic conception of the created world in surprising and powerful ways, and it is without a doubt one of the most interesting parts of her metaphysics.

Strangely, though, she does not appeal to monism when she makes her case against essentialism about species membership. There, as I will argue, she relies upon metaethical considerations instead.

\section{The Participation Argument}

Conway describes her target as the view that we must assign "specific entities...their own distinct essences and attributes [specificas rerum Entitates in distinctis suis Essentiis \& Essentialibus attributis]" (CC 32; L 92). She says little more than this to characterize the view she has in mind, but it is clear from her examples - which range from humans and horses to ice and stones - that the species in question need not be biological. We might more broadly understand her concern to be with natural kinds, or sortal properties that carve the created world into two or more nonempty classes. ${ }^{14}$ With this caveat in place, the view at issue can be called

\section{Essentialism about species membership:}

The essence of a created individual includes that individual's species.

Now, one very straightforward reason Conway has for rejecting this view is that, as we have seen, she is an essence monist: she believes all creatures share the same essence. Insofar as she allows for the existence of more than one species, she has reason to reject the claim that the essence of a created thing refers to any species more fine-grained than being $a$ created thing. The interpretation of Conway's monism has been the subject of much recent debate, but all parties to the debate concur on this point. ${ }^{15}$

I agree that Conway's ontology gives her reason to reject essentialism about species membership. Strikingly, though, the passage in which Conway actually does reject that thesis explicitly appeals only to the fact that it would place limits on creatures' "participation in divine goodness" (CC 32), which Conway regards as potentially "infinite" or unlimited. That is, although Conway has ontological resources to reject essentialism about species membership, the argument she actually uses is one that provides metaethical reasons for rejecting that view instead.

\footnotetext{
${ }^{13}$ Notably, Conway also recognizes that some forms of materialism are consonant with the rejection of species essentialism; see her comparison of her view to Hobbes' materialism at CC 65.

${ }^{14}$ The interpretation of 'species' in this context as referring to natural kinds is shared by Lascano. Her 2013, 335 n. 10, develops the reading as clearly as I have seen. Loptson suggests in his Introduction to the Principles that we should understand Conway's view as the thesis that there are no natural kinds; see his 1982, 17. However, he takes this to require Conway to accept a haecceitistic theory of individuation and identity. The rejection of species essentialism as defined here does not in fact force Conway to accept haecceities, and I want to be clear that I am not attributing such a view to her. Emily Thomas 2018 develops a persuasive alternative to Loptson's haecceitistic interpretation.

${ }^{15}$ See note 12 above.
} 
To understand these reasons, it will be helpful to examine more closely her conception of the good. On Conway's view, strongly influenced by her studies of Plato and Plotinus, all creatures participate to some extent in divine goodness. ${ }^{16}$ For all creatures are created by one and the same divine substance, and as we have seen, Conway takes this to imply that all creatures inherit that divine substance's communicable attributes in a limited degree-including, among other things, goodness and justice. Now, the manner in which any individual creature participates in these divine attributes at any time during its existence will be contingent upon its species. For instance, Conway writes that a horse is "a creature endowed by its creator with different degrees of perfection, such as not only bodily strength but also certain notions, so to speak, of how to serve his master" (CC 32). ${ }^{17}$ Presumably a good human life will involve activities quite different from those involved in a good horse life. But both forms of life are ways of participating in the good.

Taken on its own, this is not a particularly novel view. It recalls Plotinus' conclusion at Enneads I.4, already quoted, that " "living'... is used in one way of plants, in another of irrational animals, in various ways by things distinguished from each other by the clarity or dimness of their life; so obviously the same applies to "living well"' (181). However, Conway holds not only that all creatures participate in divine goodness, but that all creatures have an unlimited potential to increase their degree of participation in the good. It is this view, I argue, that motivates her to reject essentialism about species membership.

The explicit rationale that Conway provides for rejecting essentialism about species membership is, as I noted already, that it places limits on a creature's potential to participate in divine goodness. As she sees it, carving up the created world as the species essentialist does "obscures the glory of the divine attributes so that it cannot shine with its due splendor in creatures" (ibid.) Her argument runs as follows:

For if a creature were entirely limited by its own individuality and totally constrained and confined within the very narrow boundaries of its own species to the point that there was no mediator through which one creature could change into another, then no creature could attain further perfection and greater participation in divine goodness [nec ulla ad ulteriorem perfectionem, majoremque divinae bonitatis participationem evehi], nor could creatures act and react upon each other in different ways. (CC 32)

I take it that in this passage Conway is offering us a modus tollens with an implicit premise:

1. If the essence of a creature includes its species, then its species would place limits on its potential to "attain further perfection and greater participation in divine goodness" (CC 32).

2. There are no limits to a creature's potential to attain further perfection and a greater degree of participation in divine goodness.

3. So, the essence of a creature does not include its species.

\footnotetext{
${ }^{16}$ In his Preface to the Principles, CC 4, Henry More writes of "her persuing... of both Plato and Plotinus" in Latin translation.

${ }^{17}$ At CC 32, Conway attributes a variety of paradigmatically human mental states and cognitive abilities to nonhuman animals: "In addition, a horse exhibits anger, fear, love, memory, and various other qualities which are in human beings."
} 
The thought seems to be that if the species of a creature were essential to it, this would impose a fixed limit on that creature's degree of participation in the good. But this would be in some sense to limit "the glory of the divine attributes" insofar as they are manifest in creation, or so Conway seems to think. Call this the Participation Argument against essentialism about species membership.

The justification for the first premise in the Participation Argument is straightforward enough. Even the best and noblest horse remains stymied by principled moral reasoning, or for that matter by the use of a doorknob. The form of a horse, the shape of its body, the structure of its brain: all of these characteristics serve both to define and to constrain its potential to participate in the good. Thus, if the essence of a particular creature includes being a horse, inscribed within its very nature are certain limits on the degree to which that creature can participate in the good.

This thought is clearly connected to the problem I described at the outset. What Conway has recognized is that if essentialism about species membership is true, there could be no genuine facts about whether an individual would be better off if it were in a state that is incompatible with its species. ${ }^{18} \mathrm{~A}$ frustrated pet owner, after her dog steals a chocolate bar from the table, says, "If only I could make you understand that chocolate will hurt your stomach! It would be so much better for you to be able to talk." The owner is imagining a world in which her dog is able to understand her warning about the deleterious effects of chocolate. Yet the dog's inability to understand such things is part and parcel of his canine nature. The species essentialist concludes that the owner is imagining an impossible world. For the dog to understand his owner's warning, he would have to be something different from what he is and must be: a dog.

However, where many today might be inclined to accept the antecedent and infer the consequent - concluding, among other things, that the highest good of a horse is essentially different from the highest good of a human-Conway runs the argument in a different direction. She holds that a creature's potential for participation in the good must be unlimited. A fortiori, a creature's potential must not be limited by constraints imposed by its species. If the highest good of the horse is not constrained by its horseness, it must be capable of transcending its species. Or, again, to make sense of the fact that the dog would really be better off with a degree of understanding that surpasses what any dog is capable of, we must deny that he is essentially a dog.

That is the logic of Conway's argument. Still, we might reasonably wonder why a creature's potential for goodness is supposed to be unlimited in this way. What justifies this claim? I can find little in the text to motivate this premise besides a piece of text that Conway includes in the section immediately following the presentation of the Participation Argument. There, she writes,

[S]ince the divine power, goodness, and wisdom has created good creatures so that they may continually and infinitely move towards the good through their own mutability, the glory of their attributes shines more and more. And this is the nature of all creatures, namely that they be in continual motion or operation, which most certainly strives for their further good (just as for the reward and fruit of their own

\footnotetext{
${ }^{18}$ Strictly speaking, all such conditionals would be vacuously true, since their antecedents would be necessarily false-hence my use of the weaselly "genuine" in describing the problem.
} 
labor), unless they resist that good by a willful transgression and abuse of the impartial will created in them by God. (CC 32)

The reference here to God's power, goodness, and wisdom may be shorthand for a further argument that the possibility of a creature that can attain no further perfection is incompatible with God's nature. There is no indication of how this further argument might go, except that the continual improvement of creatures serves to glorify the divine attributes. What is clear is Conway's conclusion: there are in principle no limits to the degree of goodness or perfection that individual could attain. This is the way that each individual manifests divine goodness, the way that each individual is godlike.

\section{Metaethical Consequences of the Participation Argument}

The immediate metaethical consequence of the Participation Argument is straightforward: it allows us to make sense of facts about the good of a created individual that are independent of its species. What is good for an individual is not indexed (solely) to its present species or form. Thus there is no special problem posed by evaluative facts about whether it would be good or bad for that individual to have a different species or form. Would I be better off with a dog's life or not? On Conway's view, this is a fair question, not a request for a vacuous frivolity, as an essentialist about species membership would suppose.

One objection that might be raised here, however, is that on this view it is unclear what the content of an individual creature's nature consists in, given that it does not include facts about the species to which that creature belongs. A human isn't essentially human; but then what is her essence? This may sound like a purely metaphysical concern about essences, but it leads directly to a metaethical concern as well. For we might have hoped that knowledge of a creature's essence would allow us to make judgments about its good. Most pressingly, we might have hoped that knowledge of human nature-our own nature-would lead us to knowledge of what is good for us. Conway's view seems to imply that this sort of inference will not work. The fact that I am human is not part of my essence; so it is quite possible that what is good or bad for me cannot be discerned on the basis of my humanity alone.

I think this problem is less significant than it seems. The main response is simply that Conway does allow that a great many facts about what is good or bad for an individual are determined on the basis of its present species (or form, or kind). An individual's good is grounded both in its essence, that of a created individual, and in its present species. For example, when considering her famous example of a horse, Conway writes:

Now, I ask, to what further perfection or degree of goodness of being or essence does or can a horse attain after he has performed good services for his master and has done what was and is appropriate for such a creature? (CC 32, emphasis added)

This quote indicates that the horse's good includes facts about what is "appropriate" given its species, even if these do not exhaust its good. There are facts about what is good for a horse insofar as it is a horse, and also facts about what is good for a horse (what "further perfection" it can attain) insofar as it is a created individual. A similar implication is present in one of Conway's few first-order moral discussions: 
[A] man who has a tree in his orchard that is fruitful and grows well fertilizes and prunes it so that it becomes better and better. But if it is barren and a burden to the earth, he fells it with an ax and burns it. (CC 35)

This is an odd passage, but I suggest we read it as a reflection of both facets of Conway's conception of the good. On the one hand, there are facts about what is good for the tree insofar as it is a tree - that it is good for the tree to be fruitful and fertilized, for example. On the other hand, there are facts about what is good for the tree insofar as it is a created individual - in this case, that it be cut down and thereby transformed when it can no longer reach further excellence as a tree. In light of this distinction, then, Conway can grant that many of the facts about our good are indeed grounded in our humanity.

There is another metaethical consequence of this argument-or at least Conway takes it to be a consequence of the argument—-that is perhaps harder to swallow. On Conway's view, the rejection of essentialism about species membership leads to a view we might call the universality of moral subjecthood, according to which all creatures are moral subjects. That Conway accepts the universality of moral subjecthood is clear from her discussion of "the justice of God":

We already see how the justice of God shines so gloriously in this transmutation of one species into another. ... When they become better, this justice bestows a reward and prize for their good deeds. When they become worse, the same justice punishes them with fitting penalties according to the nature and degree of their transgression. The same justice imposes a law for all creatures and inscribes it in their very natures. Whatever creature breaks this law is punished accordingly. But any creature who observes this law receives the reward of becoming better. (CC 35)

The moral law that humans must abide by is not unique to humanity, but inscribed in the nature of all creatures - and all creatures are rightly subject to reward or punishment according to their behavior.

Why accept such a view? Notably, this passage comes shortly after Conway's discussion of the Participation Argument; it seems to be a continuation of her thinking about the consequences of the view that all creatures can "attain further perfection and greater participation in divine goodness" (CC 32). The connection may seem oblique, but I think Conway has in mind something like the following line of reasoning. Once we open up questions about what a creature would be like if it were a spiritually and morally improved version of itself-treating such counterfactuals as genuine metaphysical possibilities- there is no reason to treat humans alone as subject to morality. For humans are responsible for failing to act in accordance with the divine law because (i) they have access to the law (it is inscribed in their nature) and (ii) they could have acted in accordance with it. Given that the nature or essence of a human does not include her humanity, however, it cannot be her humanity that gives her access to the divine law. As the passage just quoted indicates, the divine law is imposed upon us not in virtue of our humanity, but simply in virtue of our nature as created beings. Moreover, on Conway's view, the species of an individual does not determine what it could or could not do. Thus, even when an individual actually lacks psychological features we might take to be prerequisites for morality, nevertheless that 
individual could have had those features. ${ }^{19}$ So it is true not only of humans, but of all creatures, that they could have both (i) recognized and (ii) acted in accordance with the divine law. While this interpretation involves some rational reconstruction, it would explain Conway's readiness to consider all creatures as moral subjects, taking actions for which they may rightly be rewarded or punished.

\section{Lessons for Metaethics}

Conway's willingness to endorse the universality of moral subjecthood, if nothing else, should highlight for us the distance between her metaethical views and those in vogue today. This may make it seem as though the study of her system has little to offer the contemporary metaethicist. However, I will conclude by outlining one way in which Conway's system draws our attention to some hidden assumptions about essentialism that are at work in an influential family of contemporary metaethical views about the good.

A number of authors over the past forty years or so have developed versions of the view that a person's normative reasons-loosely, the practical or moral reasons that count for or against that person's acting in certain ways - are (or are determined by) facts about an idealized version of that person. (I'll use 'reason' as shorthand for "normative reason" from here on.) This literature is likely more familiar than the scholarly conversation on Anne Conway, so a few key examples should suffice to illustrate the general strategy. Peter Railton $(1986,16)$ writes,

[A]n individual's good consists in what he would want himself to want, or to pursue, were he to contemplate his present situation from a standpoint fully and vividly informed about himself and his circumstances, and entirely free of cognitive error or lapses of instrumental rationality.

On the assumption that a person has a reason to do what it is good for him to do, this suggests that we have a reason to do what this ideal version of ourselves would want to want in our situation. In a similar vein, Michael Smith $(1994,151)$ proposes that

[W] hat it is desirable for us to do in certain circumstances-let's call these circumstances the 'evaluated possible world'-is what we, not actually as we are, but as we would be in a possible world in which we are fully rational-let's call this the 'evaluating possible world'-would want ourselves to do in those circumstances.

\footnotetext{
${ }^{19}$ One objection here is that Conway's view renders useless the principle that ought implies can. For it seems that there are almost no moral demands that a creature could not have satisfied, on Conway's extremely permissive notion of what a creature can do or become. Thus creatures seem destined not only to be moral subjects, but to be terrible moral subjects. There are two points to make in reply to this apt concern. First, the idea of the created world as fallen and corrupt would be in keeping with Neoplatonism. I do not think she would find this implication of her view to be objectionable, even if we find it uncomfortable. And, second, I would suggest that we see Conway's view as adding a further condition for using ought-implies-can. To use that claim in an appropriately rigorous way, we would first need a principled account of what an individual can do or become. Thanks to Joseph Len Miller and Kevin DeLapp for discussion of this issue.
} 
Thus, Smith continues, "facts about what it is desirable for us to do are constituted by the facts about what we would advise ourselves to do if we were perfectly placed to give ourselves advice" (152). Again, given the assumption that we have a normative reason to do whatever it is desirable for us to do, this suggests that we have a normative reason to do what we would be advised to do by an idealized version of ourselves.

Without worrying too much about the differences among such views—which are important when weighing them against one another, but are not so important for my purposes here-we can characterize the strategy in Smith's terms. Call it the

Ideal adviser strategy: $\quad x$ has a normative reason to A iff a perfectly rational counterpart of $x$ would advise $x$ to A.

The ideal adviser strategy has a number of benefits, not least of which is that it is a naturalistic way of generating normative reasons. It also makes easy sense of many ordinary cases. (We do not typically even need to resort to a strictly ideal version of ourselves, either. Although that neck tattoo really seemed desirable when I was drunk, in the sober light of day I see that it is not really so...)

There is a significant literature raising difficulties for such accounts. ${ }^{20} \mathrm{My}$ aim here is more modest: I want to show that those who pursue the ideal adviser strategy must either accept essentialism about species membership or the universality of moral subjecthood. I will focus on biological species in developing this point, but recall that 'species' here could include all natural kinds - not only such biological kinds as being human, but also such kinds as being rational. ${ }^{21}$ The dilemma may therefore be reframed as follows: if the ideal adviser theorist wishes to reject the universality of moral subjecthood, he must hold that an individual's essence includes some natural kind (humanity, rationality, or whatever) that moral non-subjects lack.

Although Conway's metaethics is steeped in religious concerns and motivations that may seem distant from the ideal adviser strategy, notice that her basic insight is at its core a version of that strategy. Our good is determined at least in part by facts about more perfect versions of ourselves - the better creatures we may yet become. And, given that essentialism about species membership is false, the more perfect version of ourselves need not share our current traits (e.g., the irrationality of the drunk), or even be human at all. It is this basic line of thinking that leads Conway to accept the universality of moral subjecthood.

The connection Conway draws between the metaphysics of essence and the metaethics of moral agency therefore raises the question of whether a similar dynamic may be at work in the ideal adviser strategy. It seems that it is. If we deny essentialism about any species membership, it seems that it would be arbitrary to deny that nonhuman creatures such as dogs or horses have ideally informed counterparts. Given the ideal adviser strategy, we would then be forced to say of these nonhumans that they have normative reasons to do, or not to do, certain things, even if they would not normally be reckoned as agents at all.

\footnotetext{
${ }^{20}$ David Sobel 1994, 793, nicely captures the central difficulty for the ideal adviser strategy: "The idealization process turns us into such different creatures that it would be surprising if the well-being of the two of us, my informed self and my ordinary self, consisted in the same things." The difficulty is figuring out just what criteria one ought to seek in an ideal adviser.

${ }^{21}$ Thanks to Colin Marshall for raising this point.
} 
Conway, as we have seen, endorses this conclusion. I expect most contemporary metaethicists will be eager to choose differently, accepting essentialism about species membership and thereby shutting the door on Conway's menagerie of dubious moral subjects. This is an open and perfectly legitimate response. But I do not think there are other ways out that are not objectionably arbitrary. ${ }^{22}$ For example, you might be tempted to propose a restriction on the domain of individuals considered in the ideal adviser strategy, a restriction that does not rely on essentialism about species membership. Following Connie S. Rosati $(1995,301)$, for instance, we might require not only that the idealized version of $x$ would recommend something, but also that $x$ herself is "capable of caring under ordinary optimal conditions about the fact that she would care about [something] for her actual self under a specified set of ideal conditions." In other words, it is not enough that the ideal adviser would make a certain recommendation. You must also be able to care about that recommendation — and Conway's menagerie cannot do that. In this way, we might try to restrict moral subjecthood to humans (and perhaps a few other very similar creatures) without accepting essentialism about species membership.

Yet without essentialism about species membership to back it up, this proposal is arbitrary. Whether $x$ could care about the advice of her ideal counterpart "under ordinary optimal conditions" depends on what such conditions are, and it seems that what "ordinary" and "optimal" here must mean is ordinary and optimal for a member of this species. The idea is to exclude dogs, for example, as moral agents because it isn't possible for a dog to care about what his ideal adviser would recommend, even under ordinary and optimal conditions for a dog. But then-given that essentialism about species membership is not supposed to be on the table - it is hard to see what justification there could be for tacking this requirement onto the ideal adviser strategy. ${ }^{23}$

One lesson of Conway's reflections on the good, then, is that our views about the good may involve us in a great deal more metaphysical presupposition about our capacities and limits than we typically appreciate. While it is always open to us simply to accept these presuppositions when they are pointed out to us, they nevertheless represent a cost of such views that is often left hidden.

\footnotetext{
${ }^{22}$ I suspect that any attempt to fix the problem by restricting the modal accessibility relation at issue in the ideal adviser strategy will introduce some degree of arbitrariness. For instance, we might naturally want to restrict the domain of counterparts to those, roughly speaking, accessible from here and now-that is, those at suitably close possible worlds. Under this restriction, most nonhumans will lack relevantly informed and rational counterparts, so the dilemma appears to vanish. However, the restriction requires us to decide what counts as accessible from here and now, and it seems inevitable that this decision will be somewhat arbitrary. What counterparts are too distant to make the cut, and why? It is hard to see how a principled line could be drawn. Thanks to Alex King for pressing me to think more carefully about this approach.

${ }^{23}$ A similar concern afflicts other, even more carefully targeted versions of this approach. Suppose we modify the ideal adviser strategy as follows: $x$ has a normative reason to A iff a perfectly rational counterpart of $x$ who is of the same species as $x$-would advise $x$ to A. The problem is that there is no reason to add the extra clause unless we take $x^{\prime}$ s species to characterize the ideal version of $x$, a claim that seems once again to be drawn from essentialism about species membership.
} 


\section{References}

Conway, Anne. 1982. Principles of the Most Ancient and Modern Philosophy. Translated and edited by Peter Loptson. The Hague: Martinus Nijhoff.

Conway, Anne. 1996. The Principles of the Most Ancient and Modern Philosophy. Translated and edited by Allison P. Coudert and Taylor Corse. Cambridge: Cambridge University Press.

Coudert, Allison. “A Cambridge Platonist's Kabbalist Nightmare.” Journal of the History of Ideas 36 no. 4: 633-652.

Borcherding, Julia. Forthcoming. "Loving the Body, Loving the Soul: Conway's Vitalist Critique of Cartesian and Morean Dualism." Oxford Studies in the History of Early Modern Philosophy, volume 9.

Broad, Jacqueline. 2002. Women Philosophers of the Seventeenth Century. Cambridge: Cambridge University Press.

Duran, Jane. 1989. “Anne Viscountess Conway: A Seventeenth Century Rationalist.” Hypatia 4(1): 64-79.

Ficino, Marsilio. 2001. Platonic Theology, Vol. I. Translated by Michael J. B. Allen and John Warden. Edited by James Hankins and William Bowen. Cambridge: Harvard University Press.

Gordon-Roth, Jessica. Forthcoming. "What Kind of Monist is Anne Finch Conway?" Journal of the American Philosophical Association.

Grey, John. 2017. “Conway's Ontological Objection to Cartesian Dualism.” Philosophers' Imprint 17(3): 1-19.

Hutton, Sarah. 2004. Anne Conway: A Woman Philosopher. Cambridge: Cambridge University Press.

Hutton, Sarah. 2018. “Goodness in Anne Conway's Metaphysics.” In Early Modern Women on Metaphysics, edited by Emily Thomas, 229-246. Cambridge: Cambridge University Press.

Lascano, Marcy. 2013. "Anne Conway: Bodies in the Spiritual World.” Philosophy Compass 8(4): 327-336.

Loptson, Peter. 1982. Introduction to The Principles of the Most Ancient and Modern Philosophy, by Anne Conway. Boston: Martinus Nijhoff.

McRobert, Jennifer. 2000. “Anne Conway's Vitalism and Her Critique of Descartes.” International Philosophical Quarterly XL 1(157): 21-35.

Mercer, Christia. 2012. "Knowledge and Suffering in Early Modern Philosophy: G. W. Leibniz and Anne Conway." In Emotional Minds, edited by Sabrina Ebbersmeyer, 179-206. Berlin: De Gruyter.

Mercer, Christia. 2015. "Seventeenth-Century Universal Sympathy: Stoicism, Platonism, Leibniz, and Conway." In Sympathy: A History, edited by Eric Schliesser. New York: Oxford University Press.

Railton, Peter. 1986. "Facts and Values." Philosophical Topics 14: 5-29.

Reid, Jasper. 2012. The Metaphysics of Henry More. London: Springer.

Rosati, Connie S. 1995. "Persons, Perspectives, and Full Information Accounts of the Good." Ethics 105 no. 2: 296-325.

Smith, Michael. 1994. The Moral Problem. Oxford: Blackwell.

Smith, Michael. 2005. "Meta-ethics." In Oxford Handbook of Contemporary Philosophy, edited by Frank Jackson and Michael Smith, 3-30. Oxford: Oxford University Press.

Sobel, David. 1994. "Full Information Accounts of Well-Being." Ethics 104 no. 4: 784-810. 
Thomas, Emily. 2018. “Anne Conway on the Identity of Creatures over Time.” In Early Modern Women on Metaphysics, edited by Emily Thomas, 131-149. Cambridge: Cambridge University Press. 